Publisher homepage: www.universepg.com, ISSN: 2707-4668 (Online) \& 2707-465X (Print)

https://doi.org/10.34104/ajssls.020.011032

Asian Journal of Social Sciences and Legal Studies

Journal homepage: www.universepg.com/journal/ajssls

\title{
A Critical Analysis on Violation of Human Rights Caused by Extra- Judicial Killings with Special Reference to the Role of Police: Bangladesh Perspective
}

\author{
Md. Nahidul Islam* \\ Department of Law, Gono Bishwabidyalay, Savar, Dhaka-1344, Bangladesh. \\ *Correspondence: jsnahid07law@gmail.com (Dr. Md. Nahidul Islam, Assistant Professor, Department of Law, Gono \\ Bishwabidyalay, Savar, Dhaka-1344, Bangladesh).
}

\begin{abstract}
This paper mostly dwells on the certain examples of violation of human rights extremely committed by the law enforcement agency i.e., the police emphasizing on the human rights situation in Bangladesh. The utmost negative role of Police has been highlighted here considering the state of human rights regarding the violations especially caused by Extra-Judicial Killings. Furthermore, Human Rights situation demanded its due concepts with the present justice system. In this study, police administration has been taken under close scrutiny. In addition to this, an attempt has been made to unveil the relationship between Human Rights and Police Administration. Most importantly, there is a further attempt to uphold the facts of human rights' violations especially in extrajudicial killings mentioning and studying sensational cases too. Finally, in this paper, the researcher has endeavored to bring out the actual situation of violations analyzing the extra-judicial facts in different perspectives in connection with the activities of the law enforcing agencies i.e., the police where this agencies are always on action having the responsibilities to protect and ensure the human rights of the citizens in a democratic and developing country like Bangladesh.
\end{abstract}

Keywords: Critical analysis, Violation, Human rights, Extra-Judicial killings, and Bangladesh perspective.

\section{INTRODUCTION:}

At the outset, it can say what is considered to be an offense, and which means violation of the rights. When a common man does anything which is illegal in law and punishable by the court of law in a state is a crime and he who commits it, is called a criminal in the eye of law and he is guilty in this regard. But it is a matter of fact that if the protector is a spoiler, it means violating the rights. So in this connection, it would not be out of place to mention that if the police, as the keeper, does not establish the rights of the common people, but rather assaults them and by misusing their power, then it is called the violation of rights i.e., the

UniversePG I www.universepg.com human rights violations committed by the police. In a democratic and developing country like Bangladesh, human rights situation is not a small issue. It is observer by the researcher that human rights in this country are being violated in different ways. These so called violations are being done not only day after day by the police but also by various government and nongovernment organizations of the country are responsible for it. But since police breaches are the subject to this study, then the researcher tried his best attempt to hold up the overall situation of human rights relating to violation of human rights in Bangladesh especially in extra-judicial activities through his write-up. 
Therefore, while studying by the researcher in this connection, it would not be out of place to start mentioning through a common conception of the common people mentioned below to clear out attitude towards the law enforcement agency i.e., the police in a democratic country like Bangladesh. If it is said about the issue of rights, then in different perspectives, it can be noticed that people do not like to go to the police station to file a complaint. It does not feel very good to go there thinking that there will be more problems may have to be faced in the police station. In essence, by the expenditure of money, they will have to be directed to the police for their due rights. So here's the money to get right and just like getting the right to exchange money. Though the facts are incredible, it is true and difficult to believe that it is a real picture that police do not want to receive complaints in many cases not only in a democratic country like Bangladesh but also in other subcontinental countries. Since it involves questions of money and ethics thereto, therefore it is really a matter of great regret that such ideas have been developed among the most of the people in Bangladesh. Consequently, the creation of public interest in this trust is getting clear form of violation of human rights by the police now-a-days (Islam, 2019).

In fact, this kind of negative attitude towards the police was not built in a day by the common people in this country, but it is the result of some of the corrupt members of the police community though in every sector however in every such government and nongovernment organization. There are certain numbers of corrupt persons still involved. In this connection, it must be mentioned that those corrupt personnel were also under the process of law at present. Furthermore, the number of honest and qualified police is not low at present too and they are always ready to serve people the best afford ever.

Even then, it is a burning question of the day why the negative thinking is still prevailing in the heart of the common citizen in a state like Bangladesh. So therefore, the concept of violation of human rights by the police is now a matter of under the real study. That is why it became an ultimate responsibility of the law enforcers to make people turned in the right direction wherefrom such a strong idea i.e., the traditional concept against the police. In this connection, it must be mentioned that on 6 March and 7 March 2017 in Geneva, the United Nations Human Rights Committee reviewed the progress of Bangladesh in implementing the Civil and Political Rights regarding the sections of International Charter. In this review the United Nations Human Rights Committee has expressed their concerns i.e., anxieties and recommendations on matters related to civil and political rights are:

Extra-judicial Killings, Forced disappearance, Torture and death in Custody, Freedom of Expression, Death Sentence, Prison Situation, Strengthen the National Human Rights Commission, Prevention of Terrorism, Gender, Religion, Caste and Ethnic Discrimination, Child Marriage and its harmful social practice, Rights of Refugees and Political Asylum Seekers. In this context, the researcher has an attempt after reviewing the situation of Civil and Political Rights of Bangladesh especially in 2016 and 2017, a worrying figure arises. Therefore, some of the recent and nearest past incidents that occurred in different years including in 2016 and 2017 have been discussed thoroughly here below with relevant references one after another which refers to human rights violations occurred by the law enforcement agency i.e., by the police in a democratic country like Bangladesh.

\section{Violation of Human Rights through Extra- Judicial Killings by the Police in Bangladesh}

At the outset, it has been observed that in the events of contemporary law enforcement issues in a democratic and developing country like Bangladesh, the emergence of Rapid Action Battalion (RAB) in 2004 is a spectacular, highly visible (specially for black ninja type uniform) and far impacting event which is worthy of serious attention from the both sociological and political points of view.

Within a short period, this alleged elite force has made many dramatic incidents through their activities which need address for the sake of social justice. Where police is meant for 'caring for good citizens and caging for bad citizens' for the sake of the social justice, the RAB as part of the police, has turned itself as horror. 
However, the RAB was established as a part of police, like the APB (Armed Police Battalion) organizational structure by justifying non-capability of the police for not coping up with the then criminal situation. Almost three years, Bangladesh has seen of its elected political government in the post emergency period without any visible change in the area of human rights and rule of law. Despite the fact that the general election of December 29, 2008, which came to the power of the Government led by the Bangladesh Awami League for a five year tenure and people are pledged to bring change by establishing rule of law and human rights finally. Moreover, one of the essential functions of the National Human Rights Commission (NHRC) is to spread a human rights culture, and to aid the empowerment of people for the sake of better protection of human rights in the country.

Furthermore, Bangladesh is a state party to several of the central international human treaties, including the International Convention on Civil and Political Rights (ICCPR) on September 6, 2000 and the Convention against Torture and Other Cruel, Inhuman or Degrading Treatment or Punishment that prohibits the grave violations of human rights. Thus, Bangladesh is among other things, obliged to ensure that no one is subjected to torture, and that in the determination of a criminal charge, everyone is entitled to a fair and public hearing by a tribunal established by law, and to be presumed innocent until proven guilty. In fact, in a democratic and developing country like Bangladesh, there are fixed problems as partisan politics has been combined into all types of public, academic and rule of law institutions at all levels in the country. In this regard, deliberate unlawful interventions into public and rule of law affairs by the leaders and activists of the pro-ruling party and alliance, and their relatives and supporters; have contributed to the further deterioration of the existing human rights situation. Few rulings asking for an end to extra-judicial killings have been heard from the Benches of the High Court Division of the Supreme Court of Bangladesh yielding no successful result; similarly, at the High Court Division also. The judiciary appears to be unable of protecting the fundamental rights of the citizens in the face of the gross abuses of the human rights including torture, extra-judicial killings, enforced disap-

UniversePG I www.universepg.com pearances and execution which have gone on unabatedly. In this connection, it is needless to mention that the subordinate judiciary does not have judicial mindset to protect the rights of the victims of human rights abuses. Consequently, the absence of the rule of law as a result of political impunity having the criminal justice system mostly dependent on the policing system, which is highly corrupt and works as hired musclemen of the ruling political party, resulted in the deterioration of the human rights have been violated.

\section{The Emergence of Rapid Action Battalion (RAB) as a Special Unit of Bangladesh Police}

Rapid Action Battalion or RAB is an elite anti-crime and anti-terrorism unit of the Bangladesh Police. Under the command of Inspector General of Police (IGP), it consists of members of the Bangladesh Police, Bangladesh Army, Bangladesh Navy, Bangladesh Air Force, Border Guard Bangladesh and Bangladesh Ansar. It was formed on March 26, 2004, and commenced operations on April 14, 2004. Rapid Action Battalion was formed on July 12, 2003 under the Armed Police Battalion (Amendment) Act, 2003. The act was passed through the amendment of Armed Forces Battalion Ordinance, 1979. Headquarters of this unit is situated at Kurmitola, Dhaka. Each battalion of Rapid Action Battalion is commanded by Additional Deputy Inspector General rank officer or its equivalent in other forces. In fact, this special force was established to improve law and order situation in the country. This force is entrusted with undertaking intelligence work related to crime and carrying out any investigation on the direction of the government.

RAB cannot file cases with courts themselves but must be forward the cases to Bangladesh Police who will file the case with the court. Indeed, RAB replaced the short lived Rapid Action Team (RAT) which was formed in January 2003. In this connection, it is to be mentioned that Additional Inspector General of Police Anwarul Iqbal is the founding Director General of this elite unit. Since its inception, the RAB has seized a total of 3,149 illegal arms and more than 36,000 rounds of ammunition. It has also had over 500 arrests. 
Although the RAB has been successful in apprehending several high-profile terrorists, including the infamous Bangla Bhai, Amnesty International has accused RAB of lack of accountability for being responsible for numerous deaths which have been attributed to crossfire. In March, 2010, the battalion leader stated that they have killed 622 due to 'crossfire,' while some human rights organizations claimed that over 1,000 extra-judicial killings were the product of the battalion. There have also been many reports of torture. Therefore, from the point of view mentioned above it is pertinent that there should have more searches to uphold the reality regarding extrajudicial killings especially by the RAB through a deep analysis for the sake of absolute concept of violation of human rights in a democratic and developing country like Bangladesh.

\section{The Term Crossfire, Encounter or Even Gunfight Taking Place in The Name of Extra- Judicial Killings}

At the outset of the terms, it must be mentioned that the barbaric practices of extra-judicial killings and custodial torture have existed and still exit in many countries of the world. In Bangladesh, these practices started right after the country's independence and have continued till today, with different intensities at different times. The elite force 'RAB' was formed by the last BNP government in 2004 to fight serious crimes along with the police forces. They were successful to some extent in their stated missions including the arrests of some notorious militants and criminals, but in many cases they were alleged to have tortured detainees and killed many suspected criminals and extreme 'left-wing' activists without any trial ('cross-fire', 'encounter', 'shootout', or 'gunfight'). This unlawful practice reached a new height during the caretaker government which was mainly a semimilitary regime (2007-2008), and this has partially continued during the present AL government (Dr. K. M. A. Malik, 2010). Therefore here, the concern is extra-judicial killing and its legal pit wholes and boundaries. First of all it has to know the meaning of extrajudicial killing. As there is no exact definition of extra-judicial killing? It could be realized that there could be two types of killing related to the State itself. Firstly, killing within the law and Secondly, Killing beyond the law. For the first one killing would be from UniversePG I www.universepg.com the judicial process, by the court proceeding and sanctioned death penalty by the criminal justice process to an accused. On the other hand extra judicial killing represents the killings by the law enforcement agencies without going through the legal process (Nesar Ahmed 2009). Now to clarify the term 'Extra-judicial killing' some definitions and quotations are given underneath. Generally, the definition of extrajudicial killing' means execution without justice. In Bangladesh context, it can be said that extrajudicial killing means how people are being killed in the name of 'Crossfire' 'Shootout' and 'Gunfight'. In recent years, extrajudicial killing is like a form of tactic in the ongoing campaign against terrorism, which has generated considerable controversy. Extrajudicial killing is defined as a deliberated killing not authorized by a previous judgment pronounced by a regularly constituted court affording all the judicial guarantees which are recognized as indispensable by civilized peoples (Sinaltrainal v. Coca-Cola Co., 578 F.3d 1252 11th Cir. Fla. 2009).

Actually there is no excepted definition of ExtraJudicial Killing. An extra-judicial killing is the killing of a person by governmental authorities without the sanction of any judicial proceeding or legal process. Extra-judicial killings often target leading political, trade union, dissident, religious, and social figures and may be carried out by the state government or other state authorities like the armed forces and police. These extra-judicial killings are being categorized under a new vocabulary of 'crossfire,' 'encounters,' etc. (Razia, 2006). In addition to that, by May 12, 2010, at least 190 persons had allegedly been extrajudicially killed since the present government took office on January 6, 2009. Furthermore, according to the ALRC's documentation at least 240 extra-judicial killings were allegedly perpetrated in 2004; 396 in 2005; 355 in 2006; 184 in 2007; 149 in 2008; 154 in 2009; and the ALRC had documented 38 such killings so far during 2010 up until May 12, although information about other cases perpetrated during this period continues to be received (ALRC report 2010). Furthermore, these three terms- crossfire, encounter and gunfight are commonly used in law enforcement to define extra-judicial killing. In fact, Crossfire is a media created term. 
Media uses 'Crossfire' as killing of listed or arrested criminal through firing while so called escaping from law enforcing personnel where the crossfire victims have right of proper justice. In fact, Gunfight is a military term where two parties are to be involved in face to face collision.

\section{Legal Aspects of Crossfire in The Name of Extra-Judicial Killings in Bangladesh}

From point of the legal aspect regarding crossfire in the name extra-judicial killing in Bangladesh, according to the Penal Code Section- 96 to 106 as right of private defense, Every person has the right of private defense to protect his life \& properties and others life \& properties. In this regards a person can cause death or any other harm to the assailant under some certain conditions and law enforcing agencies do crossfire in exercise of their right of private defense. In this connection, after each incident an executive inquiry and a judicial inquiry are conducted to find out whether it is justified or any foul play is committed. Article 32 of part three of the Constitution of the People's Republic of Bangladesh, "No person shall be deprived of life of personal liberty saved in accordance with law." So the personnel of law enforcement agencies had been done their job within the law and such persons have done any serious acts which prohibited by law \& constitution and punishment will have to be grievous then those cases it will be legal also following with other terms and conditions. Furthermore, according to the Police Regulations of Bengal (PRB), 1943; firearms should not be used other than in emergencies. The uses of firearms are applicable in three situations: i) For selfprotection and possessing of property, ii) For foiling an illegal gathering and iii) In some cases, for making an arrest with condition. At many incidents of extrajudicial killing in the name of crossfire, law enforcing agencies use firearms for their self-protection or in certain extreme conditions that they are bound to use firearms. So in these cases, it is legal to use firearms but not to all cases.

\section{Circumstances of Crossfire in The Name of Extra-Judicial Killings in Bangladesh}

The conception of the common people regarding crossfire in Bangladesh that this is an extra-judicial killing committed by the law-enforcing agencies; to the so-called grievous offenders. Actually this is the invisible super power of the law-enforcing agencies in Bangladesh by which they give the judgment of death penalty to grievous offenders denying the existence of the Court of law. Now-a-days it is seemed that killings by law enforcement agencies are common phenomenon in Bangladesh. In 1972, the paramilitary group Jatiya Rakkhi Bahini came into force and had become infamous for its extra-judicial executions until it was absorbed into the army in 1975. Now, since the formation of the elite RAB in March 2004 and to date, $\mathrm{RAB}$ was responsible for the deaths of almost 1100 people around the country since its creation two-and-a half years earlier-an average of more than 13 per month. Such killings are again on the rise and are being categorized under a new vocabulary of "crossfire," "Extra-judicial Killings," "Encounters," "Gunfight" etc. Therefore, the government tries to justify the killings by using the term "Crossfire," which it refers to as gunfights between any alleged criminal group or "hardened" criminals and the RAB or police. The term "death in an encounter" is used in other countries to mean the same thing, but the term "crossfire" is preferred by law enforcement agencies in Bangladesh. Although some people believe that extrajudicial killing of hardened criminals helps ease the problem of "terrorism," in reality, it encourages lawlessness and aggravates "state terrorism." In different countries across the world, people in power have created an impression that killing "terrorists" without bringing them to justice can help curb "terrorism," but such extrajudicial killings, in fact, can neither bring peace nor exterminate "terrorism" rather it violated human rights rampantly.

Moreover, throughout the year, the Government which controls a huge majority having 305 out of a total of 345 seats in the Parliament including its alliances' did not say a single word about the criminalization of torture despite a Bill being pending in the Parliament for more than a year.

Torture continued in all the custodies controlled by the law-enforcement agencies as well as the security forces including the secret torture cells maintained by the armed forces dominated intelligence agencies' and the $\mathrm{RAB}$, a paramilitary force composed of officers 
deputed from the armed forces, border security force and the police but mostly dominated by the military, which was officially termed as an "elite force." In this regard, it must be noted that the government's human rights record improved somewhat due to the return of a democratically elected government and the repeal of the state of emergency. There was a slight increase in the number of extra-judicial killings by security forces; there remained cases of serious abuse, including extra-judicial killings, custodial deaths, arbitrary arrest and detention, and harassment of journalists.

The failure to investigate fully extra-judicial killings by security forces, including the deaths in custody of alleged mutineers from the BGB the border force, remained a matter of serious concern. Some members of security forces acted with impunity and committed acts of physical and psychological torture too. According to Article 6 and 2 of the ICCPR, Bangladesh respectively has the obligation to ensure the right to life of its people and to ensure prompt and effective reparation where violations occur. It is also obliged to bring legislation into conformity with the ICCPR.

Article 32 of the Constitution of the People's Republic of Bangladesh protects the fundamental right to life and liberty, stating that: "No person shall be deprived of life or personal liberty, save in accordance with law." In reality, this has not been implemented and this most fundamental right is being repeatedly violated with complete impunity [Article 2 and Article 6; The International Covenant on Civil and Political Rights (ICCPR), 1966].

In addition to that $\mathrm{RAB}$ and the police are being regularly issue press statements when a person has been killed during their operations. As a matter of routine, these statements are published in the press without the media making any efforts to verify the presented facts. A review of the statements issued by RAB between 2004 and 2006 shows that the agency presented the events that surrounded most of the deaths in almost identical terms.

Its statements typically said that a dangerous criminal was arrested, interrogated, and taken to recover hidden arms in the middle of the night. It is a matter of fact that when RAB arrived near the place where the arms were allegedly hidden, the suspect's accomplices opened fire on RAB and the suspect managed to escape. Therefore, from the point of view discussed and mentioned above that these three terms have been turned into a regular and common phenomenon led by the law enforcing agencies where most of the incidents have been occurred in a dramatic way and fewer in a fact.

Table 1: Extra-judicial Killings committed by the Law Enforcement Agencies in the year of 2009

\begin{tabular}{|c|c|c|c|c|c|c|c|c|c|c|}
\hline 栉 & 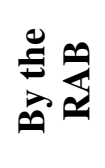 & 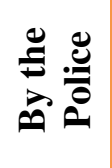 & 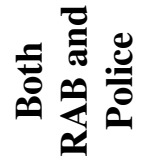 & 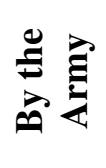 & 总 & 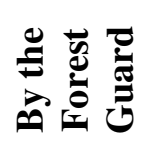 & 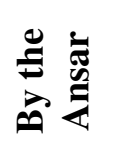 & 党总 & 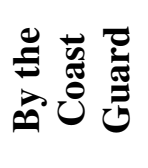 & 产 \\
\hline January & 2 & 6 & 1 & 0 & 0 & 0 & 0 & 0 & 0 & 9 \\
\hline February & 0 & 1 & 0 & 0 & 0 & 1 & 0 & 0 & 0 & 2 \\
\hline March & 1 & 0 & 0 & 0 & 0 & 0 & 0 & 0 & 0 & 1 \\
\hline April & 1 & 1 & 2 & 2 & 0 & 0 & 0 & 1 & 0 & 7 \\
\hline May & 11 & 1 & 1 & 1 & 0 & 0 & 1 & 2 & 0 & 17 \\
\hline June & 0 & 5 & 0 & 0 & 0 & 0 & 1 & 0 & 0 & 6 \\
\hline July & 1 & 1 & 3 & 0 & 0 & 0 & 0 & 0 & 0 & 5 \\
\hline August & 2 & 10 & 7 & 0 & 0 & 0 & 0 & 0 & 0 & 19 \\
\hline September & 11 & 16 & 7 & 0 & 1 & 0 & 0 & 1 & 0 & 36 \\
\hline October & 6 & 18 & 4 & 0 & 0 & 0 & 0 & 0 & 0 & 28 \\
\hline November & 4 & 9 & 0 & 0 & 0 & 0 & 0 & 0 & 1 & 14 \\
\hline December & 2 & 7 & 0 & 0 & 0 & 0 & 0 & 1 & 0 & 10 \\
\hline Total & 41 & 75 & 25 & 3 & 1 & 1 & 2 & 5 & 1 & 154 \\
\hline
\end{tabular}


Now the recorded Crime Statistics in details relating to Extra-judicial Killings by the Law Enforcing Agency i.e., by the Bangladesh Police specifically from the year 2009-2013 are mentioned here above from Table 1 to Table 5 one after another below. After analyzing the Table 1 mentioned above, it shows the crime statistics relating to Extra-judicial Killings by the Law Enforcing Agency i.e., by the Bangladesh Police in the year of 2009. In this connection, it must be mentioned that after one year of elected government by national election, during the year 2009, 154 people have reportedly been killed extra-judicially by law enforcement agencies. It is alleged that of these people, 41 were reportedly killed by $\mathrm{RAB}, 75$ by police, 25 jointly by the RAB-Police, 3 by Army, 2 by Ansar, 1 by Jail Police and 1 by Forest Guards, 5 were under the custody of BDR and 1 was a coast guard. Of the 154 killed, 35 were killed while they were in custody of the law enforcement agencies.

Table 2: Extra-judicial Killings committed by the Law Enforcement Agencies in the year of 2010

\begin{tabular}{|c|c|c|c|c|c|c|c|c|}
\hline$\sum_{\tilde{E}}^{\tilde{E}}$ & 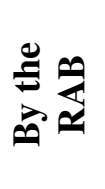 & 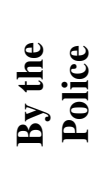 & 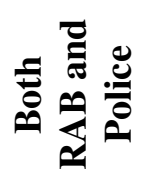 & 苋 & 总 & 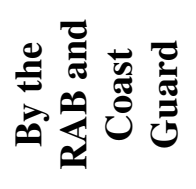 & 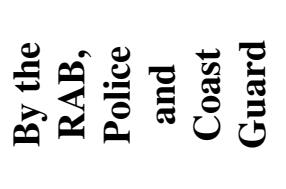 & 氶 \\
\hline January & 1 & 3 & 1 & 0 & 0 & 0 & 0 & 5 \\
\hline February & 7 & 3 & 2 & 0 & 0 & 1 & 0 & 13 \\
\hline March & 4 & 3 & 0 & 0 & 0 & 0 & 0 & 7 \\
\hline April & 5 & 4 & 0 & 2 & 0 & 0 & 0 & 11 \\
\hline May & 7 & 10 & 1 & 1 & 0 & 0 & 0 & 19 \\
\hline June & 5 & 3 & 0 & 0 & 0 & 0 & 3 & 11 \\
\hline July & 2 & 4 & 1 & 0 & 0 & 0 & 0 & 7 \\
\hline August & 6 & 2 & 0 & 0 & 0 & 0 & 0 & 8 \\
\hline September & 4 & 3 & 3 & 0 & 1 & 0 & 0 & 11 \\
\hline October & 9 & 1 & 1 & 0 & 0 & 0 & 0 & 11 \\
\hline November & 10 & 5 & 0 & 0 & 0 & 0 & 0 & 15 \\
\hline December & 8 & 2 & 0 & 0 & 0 & 0 & 0 & 10 \\
\hline Total & 68 & 43 & 9 & 3 & 1 & 1 & 3 & 128 \\
\hline
\end{tabular}

After analyzing the Table 2 mentioned above, it shows the crime statistics relating to Extra-judicial Killings by the Law Enforcing Agency i.e., by the Bangladesh Police in the year of 2010. In this connection, it must be mentioned that after two years of elected government, Incidents of extra-judicial killings continued despite the government's repeated assurance that this would be stopped.

The law enforcement agencies have continued killing in the name of suspected 'criminals'; members of the radical left political parties; or simply innocent people 'by mistake' without due process of law. In 2010, 128 people were killed extra-judicially. The data shows that on average 1 person was killed extra judicially every 3 days. Out of those killed, 68 were killed by RAB, 43 by the police, 09 persons jointly killed by RAB and police; 01 by the joint operation of RAB and Coast Guard; 03 by the joint operation of RAB, Police and Coast Guard and 03 by BGB. After analyzing the Table 3 mentioned below, it shows the crime statistics relating to Crossfire by the Law Enforcing Agency i.e., by the Bangladesh Police in the year of 2011.

In this connection, it must be mentioned that during this year 2011 (January to August), out of 50 crossfire RAB had occurred 30 and Police had occurred 9; 6 by the joint operation of RAB and Police and 5 by the joint operation of RAB and Coast Guard. So here it is to be observed that the number of crossfire is respectively decreasing from previous year and law of justice is running good. This sign is good for all human to maintain their rights and it will be better if number of crime is also be decreased. 
Table 3: Crossfire committed by the Law Enforcement Agencies in the year of 2011 (January-August)

\begin{tabular}{|l|c|c|c|c|c|}
\hline Month (s) & $\begin{array}{c}\text { By the } \\
\text { RAB }\end{array}$ & By the Police & $\begin{array}{c}\text { Both RAB } \\
\text { and Police }\end{array}$ & $\begin{array}{c}\text { By the RAB and } \\
\text { Coast Guard }\end{array}$ & Total \\
\hline January & 5 & 2 & 0 & 0 & 7 \\
\hline February & 8 & 4 & 3 & 0 & 15 \\
\hline March & 5 & 0 & 0 & 0 & 5 \\
\hline April & 2 & 1 & 0 & 0 & 3 \\
\hline May & 0 & 0 & 0 & 2 & 2 \\
\hline June & 4 & 1 & 3 & 3 & 4 \\
\hline July & 1 & 0 & 0 & 0 & 6 \\
\hline August & 5 & 1 & 0 & $\mathbf{5}$ & $\mathbf{5 0}$ \\
\hline Total & $\mathbf{3 0}$ & $\mathbf{9}$ & $\mathbf{6}$ & & 0 \\
\hline
\end{tabular}

Table 4: Extra-judicial Killings committed by the Law Enforcement Agencies in the year of 2012 (JanuaryDecember)

\begin{tabular}{|l|c|c|c|c|c|}
\hline Month (s) & Crossfire & Torture to Death & Shot to Death & Beaten to Death & Total \\
\hline January & 5 & 0 & 1 & 0 & 6 \\
\hline February & 11 & 2 & 0 & 0 & 13 \\
\hline March & 10 & 1 & 1 & 0 & 12 \\
\hline April & 9 & 1 & 1 & 0 & 11 \\
\hline May & 3 & 0 & 0 & 0 & 3 \\
\hline June & 0 & 1 & 1 & 0 & 2 \\
\hline July & 3 & 0 & 3 & 0 & 6 \\
\hline August & 0 & 1 & 0 & 0 & 1 \\
\hline September & 6 & 0 & 0 & 2 & 6 \\
\hline October & 1 & 0 & 1 & 0 & 4 \\
\hline November & 3 & 0 & 0 & 0 & 3 \\
\hline December & 2 & 1 & 0 & $\mathbf{2}$ & 3 \\
\hline Total & $\mathbf{5 3}$ & $\mathbf{7}$ & $\mathbf{8}$ & $\mathbf{7 0}$ \\
\hline
\end{tabular}

Table 5: Extra-judicial Killings committed by the Law Enforcement Agencies in the year of 2013 (January-June)

\begin{tabular}{|l|c|c|c|c|c|}
\hline Month (s) & Crossfire & Torture to Death & Shot to Death & Beaten to Death & Total \\
\hline January & 5 & 0 & 2 & 2 & 9 \\
\hline February & 7 & 1 & 72 & 1 & 81 \\
\hline March & 5 & 0 & 47 & 0 & 52 \\
\hline April & 5 & 0 & 2 & 0 & 7 \\
\hline May & 4 & 3 & 18 & 0 & 25 \\
\hline June & 5 & 2 & 1 & 1 & 9 \\
\hline Total & $\mathbf{3 1}$ & $\mathbf{6}$ & $\mathbf{1 4 2}$ & $\mathbf{4}$ & $\mathbf{1 8 3}$ \\
\hline
\end{tabular}

After analyzing the Table 4 mentioned above, it shows the crime statistics relating to Crossfire, Torture to Death, Shot to Death, and Beaten to Death by the Law Enforcing Agency i.e., by the Bangladesh Police in the year of 2012. In this connection, it must be mentioned that during this year 2012, out of 70 crossfire had occurred 53;8 had been killed through Shot; 7 had been killed through Torture and 2 had been killed through beaten by LEA i.e., by the Bangladesh Police. 
So here it is to be observed that gradually the numbers of crossfire are respectively decreasing from the previous year. Most importantly, during this year Extra-judicial Killing by law enforcement agencies are also decreased. It indicates the good governance where people start living with peace and security.

After analyzing the Table 5 mentioned above, it shows the crime statistics relating to Crossfire, Torture to Death, Shot to Death, and Beaten to Death by the Law Enforcing Agency i.e., by the Bangladesh Police in the year of 2013. In this connection, it must be mentioned that during this year 2013 (January to June), most importantly the period of the present Government, Extra-judicial Killing by law enforcement agencies are increased because of internal conflict with opposite leaders. During this year some burning issues such as justice of War criminal, Bane of Jamati Islam which creates external conflict. Hartal was found more frequently in the year of 2013. In addition to that it has been observed that the opposite leaders always wanted to damage the reputation of existing government through organizing their narrow activities of politics in international perspective in this regard.

\section{CASE STUDY}

\section{Case Study 1: Lemon Hossen Case}

The researcher has an attempt to uphold the actual fact regarding the heinous role of RAB-8 towards the victim Mr. Md. Lemon Hossen, through an interview with him on the basis of witnesses and examination of relevant documents collected from different mass media mentioned here below:

Case Description in details - Md. Lemon Hossen, a 16-year-old student of the Kathalia P. G. S. Multilateral High School and College and an examinee of the (currently ongoing) Higher Secondary Certificate (HSC) examination under the Bangladesh Technical Education Board of Dhaka. Lemon's family lives in Saturia village under the jurisdiction of the Rajapur police station in Jhalkathi district. His father Mr. Tofazzel Hossen is a day-labourer by profession while his mother Mrs. Henoara Begum is a housewife. On March 23, 2011, at around 3:30 pm, Lemon was asked by his mother to bring the family's cattle from the bank of the Sondha River where three cows were left for grazing. At around 4pm, while returning home Lemon was stopped by a group of nine persons riding three motorbikes (three persons on each bike). Among them one man was plain clothed while the rest eight were wearing the black uniform of the Rapid Action Battalion (RAB). The plain clothed man, who was later identified as Md. Lutfor Rahman, Deputy Assistant Director (DAD) of the Crime Prevention Company No. 01 of the RAB-8 based in Barisal city, asked Lemon's name and started beating accusing him (Lemon) to be a 'terrorist.' Lemon, who used to manage his tuition fees by working as part-time labourer at local brick factory due to his family's unaffordability, claimed that he was student informing the name of his college. He also requested the RAB men to contact the principal of the Kathalia P. G. S. Multilateral School and College to verify his studentship. DAD Lutfor and his colleagues denied to accept Lemon's statement and attempted to kill him by pointing gun at him. Lemon cried in fear and requested the RAB personnel for not to kill him. Suddenly, DAD Lutfor shot him pointing gun in his left thigh.

Lemon fell on the ground and lost his sense. The news of Lemon's shooting at Lemon in broad day light reached his relatives and neighbours immediately. Lemon's mother Mrs. Henoara Begum along with his uncle Moazzem Hossen rushed to the scene and saw that Lemon was bleeding from his left leg. When the mother and uncle cried out for help for saving the life of Lemon the members of the RAB prevented them from approaching Lemon.

The RAB members started beating Moazzem. DAD Lutfor grounded Moazzem and stood on Moazzem's head and neck with Lutfor's boot while the other colleagues held his hands and legs in order to stop Moazzem's movement. The RAB personnel took off the lungi (a clothed worn by males in Bangladesh and few neighbouring countries) from Lemon's body making his body naked. They put the lungi on the blood, which came out from Lemon's body, and stamped with their boots to wipe the blood from the ground with the lungi and threw the blood-soaked cloth into the river. 
The RAB personnel took off Lemon's shirt to tie up the bullet wound. After about two hours four persons carried Lemon's body to a boat at a nearby boat pier and asked the boatman Mr. Munsef to play the boat, which left for unknown place. The family became worried about Lemon's fate and the deteriorating health condition of Moazzem, who was critically injured due to torture by the RAB. They took Moazzem to the Kawkhali hospital for treatment. They learned from the eyewitnesses that a black pickup van of the RAB took away Lemon's body from a pier near to Jamaddar Bari. Since then, Lemon's whereabouts remained unknown to the family. Later, in the evening, Lemon found himself at the Sher-E-Bangla Medical College Hospital in Barisal city when he returned to his sense. In the late night, DAD Lutfor filed two criminal cases (No. 10 and 11) with the Rajapur police station accusing Lemon and seven others claiming an incident of encounter between a so called group of terrorists and the RAB-8, which is habituated to publicize fake stories of encounter since its inception.

The first case (First Information Report- FIR No. 10 of the Rajapur police station, dated March 23, 2011) was registered under Sections $19 \mathrm{~A}$ and $19 \mathrm{~F}$ of the Arms Act-1878. In this case DAD Lutfor claimed that a group of terrorists of the Shahid Jomaddar's gang opened gun fire targeting the RAB team when the latter reached Shahid Jomaddar's house. RAB responded the gunshots by firing from their own pistols and Stenguns. The terrorists escaped except one person named Lemon, who had a bullet wounds in his left thigh, with a USA-made pistol and magazines in his possession. The second case (First Information Report- FIR No. 11 of the Rajapur Police Station, dated March 23, 2011) was registered under Sections 322, 353, 307 and 34 of the Penal Code-1860 for obstructing the law-enforcement agencies to discharge their duties and attempting to murder. In both complaints the RAB's DAD Lutfor claimed Lemon's age as 25 years despite the fact that according to the official records Lemon's age is 16 years and 3 months only. They have also insisted the hospital staffs to record the same age of Lemon when he was brought to the Sher-E-Bangla Medical College Hospital in Barisal. On 24 March, at 10am Lemon's family came to know that Lemon had been admitted to the Sher-EBangla Medical College Hospital in Barisal. When the relatives went to the hospital they saw four armed men of the RAB cordoned Lemon at Bed No. 11 of the Surgical Ward No. 27. The RAB men refused Lemon's father Mr. Tofazzel to see his son. Lemon's mother Mrs. Henoara, as a form of extreme submissiveness and request, held legs of the on-duty $\mathrm{RAB}$ personnel requesting them to allow her to see her son. Then, they allowed Henoara to go to see her son, but after a short while they kicked out her from the hospital. The family learned that Lemon was admitted to the Sher-E-Bangla Medical College Hospital at 8 pm on 23 March, after four hours of the shooting Lemon by the RAB.

After the midnight of March 24, the doctors of the Sher-E-Bangla Medical College Hospital confirmed that they were unable to cure Lemon, who had a perforation in his left thigh due to bullet wounds. On 25 March, the doctors referred Lemon to the National Institute of Cardiovascular Disease (NICVD) for better treatment. The doctors of the Sher-E-Bangla Medical College Hospital implied that Lemon's condition was critical and life-threatening for which huge amount of money will be required to save his life. The family became worried about money. The people of Lemon's neighborhood donated money for his treatment although it was not enough that compelled the helpless family to borrow money mortgaging a piece of land.

In the evening of March 26, the Rajapur police cordoned by Constables Aftab and Abdur Rashid took Lemon to the NICVD in the city of Dhaka by an ambulance forcing Lemon's family to pay BDT $5,500.00$ for the fare of the ambulance. When Lemon was taken to the NICVD early in the morning of 27 March the doctors further referred him to the National Institute of Traumatology, Orthopedic and Rehabilitation (NITOR) for required treatment. On March 27, the doctors of the NITOR operated on Lemon's left and finally amputated it from the thigh of which all the tissues were found completely damaged due to bullet wounds. Lemon has been under treatment of the doctors of the NITOR, who imposed all the expenditure of Lemon's surgery upon the family. 
The members of the RAB cordoned the hospital after Lemon had been taken to the NITOR and continued surveillance. On 6 April, a leading national daily newspaper published a detailed report about the incident with a picture of Lemon's amputated leg. Since the media report the RAB and police forced the authorities of the NITOR to lock the hospital ward where Lemon was admitted. All the doors of the ward were locked from inside expelling the relatives of other patients and denying entry to visitors at that ward. The journalists, human rights defenders and lawyers were refused entry to the hospital by the uniformed and plain-clothed members of the RAB and the police. The Chairman of the National Human Rights Commission (NHRC) of Bangladesh Prof. Mizanur Rahman has only been allowed to visit Lemon, who described the story to him. The NHRC Chairman suggested the parents of Lemon to file complaints to seek justice from the court of law. Following the suggestion of the NHRC Chairman when Lemon's relatives tried to consult with lawyers regarding filing complaint with the local Court of Magistrate of Jhalkathi district the members of the RAB have started intimidating and threatening everyone of the whole area in Jhalkathi including the journalists, lawyers, relatives and neighbors for expressing their opinion regarding the barbarity of this paramilitary force, which has earned reputation of an "official death squad of the Bangladesh Government."

Moreover, the officials of the RAB have been calling many people over cell phones asking them to go to the office of the RAB-8 and keep silent about the case of Lemon. A large number of plain-clothed members of the RAB have been staying in Saturia village and collecting the names of and other particulars of the persons, who have already shared their views with the newspapers and donated money to Lemon's family for his treatment. The well-wishers and neighbours of Limon have now been forced to go in hiding in fear of extra-judicial killing by the RAB. Additionally, the plain-clothed members of the RAB have cordoned the Ward of the NITOR denying entry of the attendants of the patients, who have been helpless for getting food, medicine and assistance for using washrooms while hospital does not provide adequate support and care of the patients.
Lemon's father Mr. Tofazzel Hossain told the Asian Human Rights Commission (AHRC) that his family has seen an unimaginable disaster due to the atrocities of the RAB. He pointed out that, firstly, his son, who had passion of maintaining study by part-time working in brick factory, has been a physically disabled for his whole life. Secondly, as a day labourer Tofazzel cannot afford the high expenditure of medical treatment of his son as the public hospital asked his family to buy all medicines and necessary tools for the surgery and the post-operation medical treatment. He has already spent BDT $150,000.00$ for his son's treatment, which has also been cordially supported by the people of all walks of his native village and by selling a piece of his land. He is highly confused about the fate of his son as the family's affordability is on the verge of its last limit. Thirdly, Tofazzel's hope for getting justice has been diminishing due to continuous threats and intimidations by the RAB to his relatives, neighbours and other professionals who have expressed their sympathy to his family. Tofazzel asked when the AHRC interviewed him, "Can anyone imagine how we have been suffering from this disastrous situation? Is there any mechanism to stop the barbarity of the RAB in this country?"

Additionally, it must be mentioned that the Asian Human Rights Commission (AHRC) has learned there is another person named Morshed Jamaddar, who lives in Dhaka and reportedly employed in a private company, in the area where Limon was shot by the RAB-8 on 23 March 2011. This Morshed Jamaddar, aged around 25 years, is a son of Belayet Jamaddar, having a relationship with Mr. Shahid Jamaddar whom the RAB team accused in the two criminal cases lodged after shooting Lemon Hossen, who is 16-yearold college student. In this connection, it has been observed that the RAB, which is termed as an "elite force" by the Government of Bangladesh, did not bother for verifying the identity of a targeted person regardless whether the person concerned is innocent or involved in any kind of offence due to its extreme lack of minimum efficiency of law-enforcement. So in a nutshell, Lemon Hossain, a juvenile college student at Jamaddarhat at Rajapur Upazila in Jhalakati, was shot at by RAB-8 personnel near his house on March 23, 2011, triggering local and international outcry. 
His left leg had to be amputated as a result by the doctors of the National Institute of Traumatology, Orthopedic and Rehabilitation (NITOR) as all the tissues were found completely damaged. The battalion filed two cases that day with the Rajapur police implicating Lemon in an arms case and accusing him of obstructing police duties. The government finally decided to withdraw the cases against Lemon on July 9, 2013, citing his need to return to a "healthy and normal life."

In 2017, regarding the case, mentioning the Naraji, Lemon asked for a judicial inquiry to the court of Additional District and Session Judge at Jhalkathi. But the court later did not let the case investigate under the judicial inquiry rather permitted the case for the investigation under the TBI (Traumatic Brain Injury) in 2018, said Lemon Hossen while taking an interview. According to victim's language, "it is now still under the investigation."

Additionally, it is necessary to mention that the victim Lemon Hosssen told in the interviewer i.e., the researcher of this study that regarding the case, mentioning the Naraji, Lemon asked for a judicial inquiry to the Chief Judicial Magistrate Court at Jhalkathi but the court didn't receive the case before presenting it to the Court of Additional District and Session Judge at Jhalkathi. Finally, it is pertinent to mention that wrong spelling of a person sometimes may connect to cause a great responsibility or liability for doing anything else according to law. So, taking this question into the mind of the researcher and while asking such question about the right spelling of the victim's name.

On his reply, the victim (Lemon Hossen) asked to various mass media to make the correction of the wrong spelling of his actual name but it was of no use, he said. He told that the correct spelling of his name is Md. Lemon Hossen but ironically most of the mass media even in some reputed newspapers and journals have been used his name which is still wrongly spelled in Md. Limon Hossen or sometimes Md. Limon Hossain. So it should be corrected soon, he said.

Case Summary - Furthermore, it can be said that regarding this case, the Asian Human Rights Com- mission (AHRC) has received credible information that the Rapid Action Battalion (RAB) has shot a juvenile college student causing a permanent disability in Jhalkathi district. On March 23, 2011, a team of the RAB-8 stopped 16-year-old Lemon Hossen, who was an examinee of the Higher Secondary Certificate near to his house and him in his thigh on the suspicion that he was a terrorist. As a result of this deliberate shooting the left leg of Limon has been amputated by the doctors of the National Institute of Traumatology, Orthopedic and Rehabilitation (NITOR) as all the tissues were found completely damaged. The RAB, which is reputed to be the "official death squad of the Bangladesh Government" has then blocked off the whole ward of the hospital denying all the attendants of the patients at the hospital. The plain-clothed members of the RAB were intimidating and threatening the relatives, neighbours, journalists, lawyers and human rights defenders who are supporting the victim financially to receive treatment and express sympathy to the family. People of the victim's neighbourhood were then hiding to save their life in fear of extrajudicial killing at the hands of the RAB.

Therefore, most importantly it is to be mentioned that brutally attacked by the law enforcers i.e., by the RAB without obeying and following the proper procedure regarding arrest rather committed illegal arrest; arbitrary detention; torture; fabricated charges; death threat; intimidation; impunity and violation of rule of law that may be caused to extra-judicial killing if the victim, Md. Lemon Hossen would have not been alive today through that heinous practice of enforcing the law by the RAB-8 in the name of ensuring security for the citizens rather violating the human rights in a democratic and developing country like Bangladesh.

\section{Case Study 2: Narayanganj Sensational 7-Murder Case}

The researcher has an attempt to uphold the real scenario regarding the violation of the law enforcers involving with certain number of civilians committed in the said Narayangonj Sensational 7-Murder Case in a democratic and developing country like Bangladesh through studying this case mentioned in details here below: 


\section{Case Description in Details with Timeline:}

\section{In the Year of 2014}

The Seven people abducted - On April 27, 2014; Narayanganj City Corporation (NCC) panel mayor Nazrul Islam and senior lawyer Chandan Sarker, among seven people were abducted from DhakaNarayangonj link road. Following the incident, followers of Nazrul vandalized vehicles in Signboard on the link road and blocked it for some time.

Connection of Local Awami League men who was behind it - On April 27, 2014; wife of abducted victim Nazrul Islam, Selina Islam alleges that Nur Hossain, a councilor of ward-4, and Haji Mohammad Yasin, general secretary of Siddhirganj unit of Awami League, were behind the abduction. But Nur Hossain, also vice-president of Siddhirganj unit of AL, refutes the allegation.

Case filed by the wife of the victim against the culprits - On April 28, 2014; Selina Isla, wife of Nazrul, filed the case with Fatullah Police Station in Narayangonj against Nur Hossian, councilor of ward-4, and Haji Mohammad Yasin, general secretary of Siddhirganj unit of Awami League, who allegedly masterminded the abduction.

Biography of Nur Hossain - Born at Simrail of Siddhirganj upazila in Narayanganj, Nur Hossain used to be a helper to a trucker in late 70's. In the 70's, he became a truck driver within a few years. He then joined Narayanganj Truck Drivers' Union and became its president. He indulged in extortion in the transport sector, drug peddling, tender manipulation, river encroachment, and illegal sand trade in Siddhirganj and Fatullah. Their rivalry reached its peak when Nazrul defeated Nur in the panel mayor election of 2011 by a single vote. He paid the RAB officials to abduct and kill Nazrul.

Names of RAB, Police officials' surface - On April 29, 2014; Two days after the murder, 3 RAB officials including Lt. Col Tareque Sayeed Mohamamd, RAB11 commanding officer, were withdrawn from their duties. Meanwhile, Home Ministry recommends withdrawal of Syed Nurul Islam, superintendent of police; Akhtar Hossain, officer-in- charge of Fatullah Police Station; and Abdul Matin, Officer-in-Charge of Siddhirganj Police Station.

Dead bodies recovered floating in the Shitalakkhya River - On April 30, 2014; In a shocking turn of events, the bodies of Narayanganj city councilor Nazrul Islam and five others were found floating in the Shitalakkhya river, three days after the abduction. And the $7^{\text {th }}$ body was found in the river finally on May $1,2014$.

Naranganj units in Grief - On May 2, 2014; Local lawyers observed hartal in protest of the abduction. Thousands joined the namaz-e-janaza on DhakaChittagong highway for Nazrul Islam and his driver Jahangir who were abducted, murdered and dumped into the Shitalakkhya River.

People became Enraged - On May 2, 2014; the business office of Nur Hossain in Similar of Narayanganj is on fire after it was set alight by angry locals.

Nur Hossain Escapes - On May 3, 2014; Police raid Nur Hossain's house but did not find him i.e., the main accused in the 7-murder case fled safely; microbus seized by the police.

"RAB official Killed Nazrul for Tk. 6 Crore" - On May 4, 2014; Nazrul's father-in-law Shahidul Islam alleged RAB men killed Nazrul in exchange for Tk. 6 crore from Nur Hossain and other accused. Awami League lawmaker "Nur indeed committed the crimes," said Shamim Osman. Police seized a car of Nur's younger brother on suspicion, from a glass factory owned by a relative of Shamim Osman. Locals observed a daylong hartal in Narayanganj demanding arrests of the accused. Finally, the case was handed over to the DB.

Cops Searches for Nur Hossain - On May 5, 2014; Shahidul claims a son of AL lawmaker brokered the Tk. 6 Crore dealt with RAB personnel. The High Court ordered govt. to form a probe committee with no RAB men in it. The home ministry issued a red alert on the borders for Nur Hossain. On May 6, 2014; Shahidul and Selina gave statements to the police. 
One more case was filed and Court Ordered Arrest of Sacked RAB Men - Additionally, is to be noted that another case was filed over killing lawyer Chandan Kumar Sarkar and his driver on May 11, 2014. On May 11, 2014; The High Court ordered arrest of sacked RAB officials i.e., the three ex-RAB men were: Lt Col Tareque Sayeed Mohammad, Major Arif Hossain and Lt Commander SM Masud Rana.

Culprits must be punished, PM Said - On May 13, 2014; our honorable Prime Minister Sheikh Hasina tried to console the bereaved family members of Narayanganj seven-murder victims as they met her at the Gono Bhaban.

Finally 3 Ex-RAB officials were arrested - It was May 16, 2014; Lt Colonel Tareque Sayeed Mohammad and Major (retd.) Arif Hossain was arrested under the section 54 of the Code of Criminal Procedure at Dhaka cantonment. In early hours of May 17, another former RAB man, Navy's Lt. Commander M Masud Rana, was arrested by the law enforcers from Dhaka Cantonment area and handed him to Narayanganj police. It is to be noted that the RAB officials were sacked before they were arrested.

Nur Hossain held in Kolkata - On June 14, 2014; Indian law enforcers (cops late night) arrested Nur, the prime accused in the murder case, and 2 of his aidesShamim and Rafiq in Kolkata.

Nur Hossain Charged for Intrusion in India - On August 29, 2014; Indian investigators press charged against Nur for intruding into the country. The charge sheet stated that Nur Hossain did not have any valid document to enter India.

\section{In the Year of 2015}

Charged: Nur, 3 Ex-RAB officials among 35 for 7Murder - On April 8, 2015; nearly a year after the bloodcurdling 7-murder, cops submitted charge sheet in the sensational case, naming 35 people, including prime accused Nur Hossain and 3 sacked RAB officials. As many as 127 people, including several RAB personnel, gave statements as witness.
Arrest warrant against 13 Fugitives including 8 RAB officials - On July 8, 2015; A Narayanganj Court issued arrest warrant against 13 fugitive accused, including eight RAB officials. The court ordered authorities concern to confiscate properties of the 13 fugitives.

Nur Hossain brought back from INDIA - On November 12, 2015; Nur Hossain was brought back from India. Nur Hossain was wanted in almost a dozen cases, including Narayanganj 7-murder. The deportation took place a day after the Bangladesh government handed over top ULFA leader Anup Chetia to the Indian authorities. The founding member of one of Indian's top insurgent groups ULFA had been in prison since his arrest in Mohammadpur in December 1997.

Nur Hossain had been sent to jail - On November 13, 2015; a Court in Narayanganj sent Nur to jail after cops had produced him before it. Most importantly, it is to be mentioned that on December 1, 2015; the High Court observed that the perpetrators may have been benefited if the trial proceedings were delayed for a long time.

In the Year of 2016 - On January 3, 2016; Tareque was moved to Dhaka Medical College Hospital from Dhaka Central Jail as he felt pain in the legs, waist, and spinal cord.

Charged had been framed against 35 people - On February 8, 2016; A Narayanganj Court framed charges against 35 people, including Nur Hossain and three fired RAB officials, in two cases field in connection with the 7-murder. The court fixed February 25 for starting trail through the recoding of witnesses' testimonies. On February 2016; recording of witness testimonies began keeping journalists out of the courtroom. On March 13, 2016; Nur filed two petitions with the $\mathrm{HC}$ seeking scrapping of his trial.

Trial begins at lower court - On March 22, 2016; the High Court cleared the way for a lower court to begin trial proceedings against sacked RAB official Tareque Sayeed. 
Trial ends, verdict set on January 16, 2016 - On November 30, 2016; A Narayanganj concluded trial of the accused and fixed January16 next year for delivering its verdict on the 2014 sensational seven murders. The date was set after the completion of the defense arguments in favour of 23 arrested accused and 12 fugitives at the court. The victims' families and the state counsels expressed the hope for the highest.

\section{In the Year of 2017}

26 Accused got death penalty among the 35 for 7murder - On January 16, 2017; Justice finally catches up with them as a Narayanganj District Court delivered verdict of death penalty for 26 accused including 25 former $\mathrm{RAB}$ officials and expelled ruling AL man Nur Hossain found guilty of abduction and murder of seven people and destroying evidence among the 35 peoples in April 2014.
Death for 15, life term for 11- On August 23, 2017; the High Court revised lower court verdict in sensateional 7-murder case and on August 22, 2017; upheld the death penalty of 15 , including three ex-RAB officials and expelled Awami League leader Nur Hossain, for their involvement in conspiracy, abduction and killing of seven Narayanganj men in 2014. The court, however, commuted the capital punishment of 11 others to life imprisonment. It fined them Tk. 20,000 each, in default of which they have to spend two more years in prison. Furthermore, it is pertinent to mention that a total of 23 among the 35 accused were present in the court during the verdict. Of them, 17 were members of the Rapid Action Battalion (RAB) while 12 other accused were absconding since the incident. Most importantly, it is pertinent to mention that as journalists were about to enter the courtroom, a court employee and police personnel barred them. But later, the court intervened and allowed them in.

Table 6: The number of Convicted Persons and their awarded Penalties in Narayanganj 7-Murder Case

\begin{tabular}{|c|c|c|c|c|c|c|}
\hline \multicolumn{2}{|c|}{$\begin{array}{c}\text { Death Penalty (For } \\
\text { Abduction, Killing and } \\
\text { Hiding Bodies) }\end{array}$} & \multicolumn{2}{|c|}{ Life Imprisonment } & \multicolumn{3}{|c|}{ Imprisonment } \\
\hline \multicolumn{7}{|c|}{ Total number of convicted persons are 35} \\
\hline \multirow[t]{3}{*}{ Civilian } & \multirow{3}{*}{$\begin{array}{l}\text { Ex-RAB Official } \\
\text { and Members }\end{array}$} & \multirow[t]{2}{*}{ Civilians } & \multirow{2}{*}{$\begin{array}{l}\text { Ex-RAB } \\
\text { Members }\end{array}$} & \multicolumn{3}{|c|}{ Ex-RAB Members } \\
\hline & & & & \multirow{3}{*}{$\begin{array}{l}\text { 17-year jail } \\
\text { for abduction } \\
\text { and } \\
\text { destroying } \\
\text { evidence }\end{array}$} & \multirow[t]{3}{*}{$\begin{array}{l}\text { 10-year jail } \\
\text { for abduction }\end{array}$} & \multirow{3}{*}{$\begin{array}{c}\text { 7-year jail } \\
\text { for } \\
\text { destroying } \\
\text { evidence }\end{array}$} \\
\hline & & \multirow[t]{3}{*}{$\begin{array}{l}9 \text { (Nine) } \\
\text { Persons }\end{array}$} & \multirow[t]{3}{*}{$\begin{array}{l}2 \text { (Two) } \\
\text { Persons }\end{array}$} & & & \\
\hline \multirow[t]{2}{*}{$\begin{array}{l}1 \text { (One) } \\
\text { person }\end{array}$} & \multirow[t]{2}{*}{$\begin{array}{l}14 \text { (Fourteen) } \\
\text { Persons }\end{array}$} & & & & & \\
\hline & & & & 1(One) Person & $\begin{array}{l}6(\mathrm{Six}) \\
\text { persons }\end{array}$ & $\begin{array}{l}2 \text { (Two) } \\
\text { persons }\end{array}$ \\
\hline $\begin{array}{c}\text { Nur } \\
\text { Hossain }\end{array}$ & $\begin{array}{l}\text { Tereque Sayeed, } \\
\text { Arif Hossain, } \\
\text { Masud Rana, } \\
\text { Emdadul Haque, } \\
\text { AB Md. Arif } \\
\text { Hossain, Hira Miah, } \\
\text { Belal Hossain, Abu } \\
\text { Toiyob Ali, Shihab } \\
\text { Uddin, Purnendu } \\
\text { Bala, Al Amin, } \\
\text { Abdul Alim, } \\
\text { Mohiuddin Munshi } \\
\text { and Tajul Islam. }\end{array}$ & $\begin{array}{l}\text { Mizanur } \\
\text { Rahman Dipu, } \\
\text { Selim, } \\
\text { Sanaullah } \\
\text { Sana, Shah } \\
\text { Jahan, Jamal } \\
\text { Uddin, } \\
\text { Mortuja } \\
\text { Jaman } \\
\text { Churchill, Ali } \\
\text { Mohammad, } \\
\text { Abul Basher } \\
\text { and Raham } \\
\text { Ali. }\end{array}$ & $\begin{array}{l}\text { Asaduzzaman } \\
\text { Nur and } \\
\text { Enamul } \\
\text { Kabir. }\end{array}$ & $\begin{array}{l}\text { Habibur } \\
\text { Rahman }\end{array}$ & $\begin{array}{l}\text { Mokhlesur } \\
\text { Rahman, } \\
\text { Ruhul Amin, } \\
\text { Nuruzzaman, } \\
\text { Abul Kalam } \\
\text { Azad,Babul } \\
\text { Hasan, and } \\
\text { Kamal } \\
\text { Hossain. }\end{array}$ & $\begin{array}{l}\text { Bazlur } \\
\text { Rahman } \\
\text { and Nasir } \\
\text { Uddin. }\end{array}$ \\
\hline
\end{tabular}


However, the HC bench of Justice Bhabani Prasad Singha and Justice Mustafa Zaman Islam also upheld the jail terms of nine others for various terms ranging from seven to 17 years. So the convicted persons and their awarded penalties in Narayanganj Sensational 7Murder Case are mentioned in the Table 6.

After analyzing the Table 6 mentioned above, it shows the number of Convicted Persons and their awarded Penalties in Narayanganj Sensational 7-Murder Case in 2014. In this regard, finally among the 35 convicted persons: 1 civilian awarded Death Penalty including 14 others ex-RAB officials and members for committing abduction, killing and hiding Bodies; 9 civilians awarded Life Imprisonment including 2 others ex-RAB members and 1 ex-RAB member got 17-year imprisonment for committing abduction and destroying evidence, 6 ex-RAB members got 10-year imprisonment for committing abduction and 2 ex-RAB members awarded 7-year imprisonment for destroying evidence.

However, it has been observed from these Case Study mentioned above firstly Lemon Hossen Case and secondly 7-Murder Case, it is pertinent to mention that where the law enforcers were legally bound to protect the civilians of the country. But instead, a section of Bangladesh elite force members not only destroyed the life of the then a college going young boy named Lemon Hossen from living his life smoothly rather made it difficult causing a permanent disability in Jhalkathi district in the year of 2011 by RAB-8 but also took the lives of seven people in Narayanganj in exchange for money to serve the interest of a petty ruling party leader in the year of 2014 by RAB-11.

The horrific crime regarding 7-Murder shook the nation to its core and earned the elite crime busters a bad name because of the involvement of so many members of the disci-plined force in such a grievous offence though justice finally caught up with them. So the nation is now just still waiting for the execution of such justice. Finally, from the point of view and references mentioned above, it can be said that the practice of Extra-judicial Killing committed by the Law Enforcement Agency is still present and visible which is never and ever be acceptable and expectable because of committing such violations in the name of protecting and ensuring Human Rights in a democratic and developing country like Bangladesh. In fact, there has been observed the real scenario of the violation of Human Rights regarding Extra-judicial Killings in the Odhikar's Annual Human Rights Report on 2017.

Furthermore, Law enforcement agencies term such incidents as deaths in 'gunfight' or 'crossfire'; and in most cases they enjoy impunity, despite allegations from victim-families to the contrary. It is to be mentioned that the word 'crossfire' is used by law enforcement agencies when they carry out an operation with the detained person (victim) in the name of 'arms recovery' and where it is claimed that associates of the arrested person opened fire at the law enforcers; and members of law enforcement agencies, shot back in self defense and the arrested person was killed. In some cases law enforcers claim that incidents of gunfight or crossfire happened in a specific area, but local people there say no such incident occurred. Extra-judicial killing is a blatant example of the violation of right to life and right to personal liberty, which violate Article 32 of the Constitution of the People's Republic of Bangladesh and Article 6 of the ICCPR. According information gathered by Odhikar, 154 persons were reportedly killed extra-judicially in 2017. After analyzing the Table 7 mentioned below, it shows in details of the information of alleged killing.

Crossfire/encounter/gunfight - Among the 154 persons extra judicially killed, 139 were killed in 'crossfire/encounters/gun fights'. Of them, 104 were killed by the police, 32 by the RAB, two by the DB police and one killed by the Army.

Tortured to death - In 2017, 12 persons were allegedly tortured to death. Among them nine were killed by the police, one by the RAB, one by Army and one by BGB. 
Table 7: Information of alleged killing by law enforcement agencies from January-December: 2017

\begin{tabular}{|l|c|c|c|c|c|c|}
\hline \multicolumn{1}{|c|}{ Month(s) } & RAB & Police & BGB & DB Police & Army & Total \\
\hline January & 4 & 12 & - & - & - & 16 \\
\hline February & 1 & 15 & - & - & 1 & 17 \\
\hline March & 1 & 19 & - & - & - & 20 \\
\hline April & 1 & 8 & - & - & 1 & 10 \\
\hline May & 2 & 7 & - & - & - & 9 \\
\hline June & 2 & 11 & - & - & - & 13 \\
\hline July & 7 & 11 & - & - & - & 18 \\
\hline August & 2 & 8 & - & - & - & 10 \\
\hline September & 1 & 3 & - & - & - & 4 \\
\hline October & 4 & 10 & 1 & - & - & 15 \\
\hline November & 7 & 5 & - & - & - & 12 \\
\hline December & 1 & 7 & - & 2 & - & 10 \\
\hline Total & $\mathbf{3 3}$ & $\mathbf{1 1 6}$ & $\mathbf{1}$ & $\mathbf{2}$ & $\mathbf{2}$ & $\mathbf{1 5 4}$ \\
\hline
\end{tabular}

Shot to death - Among the deceased, one person was allegedly shot and killed by police during this period while in a protest rally.

Beaten to death - Among the deceased, two persons were beaten to death by police.

The identity of the deceased - Of the 154 persons who were killed extra-judicially, two were leaders of BNP, one was an activist of student wing of Jamaat-eIslami, one was General Secretary of Naniarchar unit Pahari Chhatra Parishad, one was a member of Parbatya Chattagram Jana Sanghati Samiti (PCJSS), one was a member of New Biplobi Communist Party (Mrinal Bahini), one was a member of Purba Banglar Communist Party, two were member of Purba Banglar Communist Party (Red Flag), one was a member of Purba Banglar Communist Party (ML Janajuddho), one was a member of Sarbahara Party, five were alleged members of Jama'atul Mojahidin Bangladesh (JMB), one was a member of Harkat-ul-Jihad-al-Islami (Huji), one was a cattle trader, one was a villager, two were businessmen, one was a carpenter, one was a farmer, one was a driver, one was a Government employee, two were persons accused in different criminal cases; one was a convicted criminal and 119 were alleged criminals. The identities of seven persons were not reported. During this reporting period, a total of 139 persons, including Sabuj Malitha alias Saddam,
Ramesh Karmokar, Kamruzzaman Kanon and Shohagh Islam of Meherpur District on March 13; Rokibul Hassan Bappi and Lalon Molla of Rajbari District on May 12; Ashraf Uddin Dhol of Mymensingh District on May 24; Alamgir of Lalbagh, Dhakaon June 9; Jalaluddin Bodu of Akhaura Upazila under Brahmanbaria Districton August 4; Shahin Ali of Kumarkhali Upazila under Kushtia District on October 13; and on December 31 Yunus Mia of Chunarughat under Habiganj District,were killed in alleged 'gunfight' between members of law enforcement agencies. It is not end here, bodies of Saddam, Romesh, Kanon and Shohagh, who were killed in 'gunfight' in Meherpur (The Naya Diganta, March 15, 2017).

The two alleged extortionists Shipon Ali, 24 and Alamgir Hossain, 26 were killed in a "gunfight" with police at a brick kiln in Hariadah of Meherpur's Gangi upazila (The Daily Star, April 16, 2017), A man named Sohel Sheikh, 30, was killed in a "gunfight" with detectives in the city's Bhashantek area early on April 17, 2017, four days after he was called out from his Ashulia house allegedly by a criminal gang (The Daily Star, April 18, 2017). Now a table has been shown regarding arrests and certain crossfire in this regard and after analyzing the Table $\mathbf{8}$ mentioned below, it shows the number certain number of notable arrests and the incidents of crossfire after it occurred by the RAB personnel. 
Table 8: Containing details of major crossfire after arrests by the RAB according to their official website.

\begin{tabular}{|c|c|c|}
\hline Name & Charge & Arrest \\
\hline Pichchi Hannan & Terrorism & 26 June 2004 , later killed trying to escape \\
\hline Debashis & Accomplice to Pichchi Hannan & killed in crossfire, 24 June 2004 \\
\hline Mollah Shamim & 10 cases including three murders & killed in crossfire, 6 September 2004 \\
\hline Shahabuddin & Extortion & Killed 26 October 2004 \\
\hline Syed Monir Hossain & $\begin{array}{l}\text { Several criminal offences, including } \\
\text { two murders }\end{array}$ & killed in crossfire, 11 March 2005 \\
\hline Shahjahan & $\begin{array}{l}5 \text { charges including murder, rape and } \\
\text { robbery }\end{array}$ & killed in crossfire, 12 January 2005 \\
\hline $\begin{array}{l}\text { Sumon Ahmed } \\
\text { Majumder }\end{array}$ & Extortion & killed "in crossfire" (see BBC article) \\
\hline Hasibul & 16 cases including 12 murder cases & $\begin{array}{l}26 \text { January } 2005 \text {, later killed attempting } \\
\text { to escape }\end{array}$ \\
\hline
\end{tabular}

It is not end here, because according to Human Rights Watch, members of Rapid Action Battalion have shot and killed women and children during public protests. Rights group describe it as a "death squad."

Another incident where a tea vendor named Babul Matabbar died of burns at Dhaka Medical College Hospital after he felt on a kerosene stove on February 3, 2018 (Wednesday night) due to refusing to pay subscription to the police. It was due to refusing to pay subscription to the police. He had been pushed by a police informant who was accompanied by some cops out to pick him up from Mirpur. So therefore in this brutal incident, it must be observed and to be noted that it was absolutely an illegal activities by the Police towards a citizen that was never be expected and accepted in a democratic and developing country like Bangladesh. In this regard, Professor Mizanur Rahman, the then chairman of National Human Rights Commission went to the hospital to see Babul but he died minutes earlier. "The audacity of police has gone to an excessive level. It should be stopped right away," chairman said to the reporters there.

\section{FINDINGS AND RECOMMENDATIONS OF THE STUDY:}

During analysis of the study, the researcher has found certain loopholes and findings along with certain recommendations regarding the role and violations of human rights committed by the law enforcers i.e., the police in a democratic and developing country like Bangladesh are mentioned here below:

1. Most importantly it is unpleasant truth to be mentioned that violation of human rights through killing by the Police has been occurred rampantly in a democratic and developing country like Bangladesh. Therefore, it is pertinent to mention that from the point of view mentioned above, as there so many other cases are the similar to this category that carried out in police stations, military garrisons, the intelligence agencies' torture cells, and paramilitary forces camps such as those of the RAB - impunity prevails. Because extra judicial killing in the name of crossfire is well known after establishing RAB where as it is started before. But it is totally violation of human rights.

2. According to Article 35(5) of the Constitution of People's Republic of Bangladesh, "No person shall be subjected to torture or to cruel, inhuman or degrading punishment or treatment." It is been observed that this provision regarding the prohibition of torture hasn't been implemented in practice, mainly because of the lack of a law criminalizing torture. There is no culture of protecting human rights in the country, particularly victims who suffer ill-treatment and torture at the hands of the law-enforcement agencies. 
3. The Rule 75 (3) of the Criminal Rules and Orders-2009, which reads: "Whenever a person is arrested and brought before the Magistrate, the Magistrate should be satisfied that there has been no unauthorized detention beyond 24 hours as provided in Section 61 of the Code of Criminal Procedure-1898 and if there be any complaint to the that effect against the police, he shall make an enquiry into the matter and take such actions as may be deemed necessary."

4. Article 31 of the constitution of People's Republic of Bangladesh says that, "To enjoy the protection of law, and to be treated in accordance with law, is the inalienable right of every citizen, wherever he may be, and of every other person for the time being within Bangladesh, and in particular no action detrimental to the life, liberty, body, reputation or property of any person shall be taken except in accordance with law." At the constitution's Article 32 ensures the protection of the right to life and personal liberty in accordance with the law. Because of the consequences of such deprivation, the drafters of the constitution made this specific provision of protection even though these rights were already covered by Article 31. These articles 31 and 32 is the right to access to justice, and it cannot be said that this right has been dealt with in accordance with the law unless a person has a reasonable opportunity to approach the court in vindication of their right or grievance. Even a fugitive is entitled to a legal defense when the death penalty is involved. So, extra-judicial killing is always gone against to the Constitution of the People's Republic of Bangladesh.

5. Furthermore, still, according to the Police Regulations of Bengal (PRB), 1943; firearms should not be used other than in emergencies. The uses of firearms are applicable in three situations: for self-protection and possessing of property, for foiling an illegal gathering and, in some cases, for making an arrest. The Police Regulations of Bengal (PRB) of 1943 mandates a full executive probe regarding any use of firearms. Investigators are required to send the report to the government and submit a copy to the police's top leadership.

6. Most importantly, according to section 197 of the Code of Criminal Procedure 1898 (Prosecution of Judges and public servants), shield government officials from being held accountable for their actions. Section 197(1) "When any person who is a judge within the meaning of section 19 of Penal Code, or when any Magistrate, or when any public servant who is not removable from his office save by or with the sanction of the Government, is accused of any offence alleged to have been committed by him while acting or purporting to act in the discharge of his official duty, no court shall take cognizance of such offence except with the previous sanction of the Government". So, this code prohibits criminal actions from being initiated against public officials-including police officers-without government approval, if the offense is committed while the officer is acting or purporting to act in his official capacity.

7. Moreover, the Supreme Court has, in several cases, declared that police officers committing murder and other human rights violations are not acting within the scope of their official duties. However, in practice the provision discourages the police and the courts from taking action against public servants. Even when permission is requested, the relevant government department often fails to grant approval. In other cases, the approval is granted only after a substantial delay, there by violating international law provisions that call for prompt investigation and prosecution of human rights abuses. Delay also allows a suspect to abscond.

8. Therefore, at this study, the information shows that crossfire is gradually occurred every year. From the table of total number of informed that the number of crossfire is increasing or decreasing in various time. But it cannot be ensured that crossfire will be stopped gradually because it is fully depending on honest desire and step taken accordingly by the government and the law enforcement agencies. In this connection, it is to 
be mentioned that 53 more alleged drug peddlers were killed in gunfights' across the country in 10 days regarding anti-narcotics drive (The Daily Star, May 25, 2018).

9. In this regard, it must be mentioned that Road Transport and Bridges Minister Obaidul Quader defended the ongoing drive saying drug peddlers were being killed "encounter" with law enforcers. According to his speech- "We don't support extra-judicial killings, but drug peddlers have a syndicate. They have ties with terrorists and armed criminals. When police go to arrest them [drug peddlers], they fight them [police] with arms. Encounter takes place. You cannot call it extra-judicial killing," he told the journalists in the capital on May 24, 2018.

10. In addition to that, whatever, some people are supporting crossfire for the lacking and weakness of our justice system and law enforcement agencies. Those people think that listed criminal are the burden of society and they are doing unlawful activities, murder, making our society unstable, case load of our justice system will be reduced; people can move and trade freely. But those people don't think that they are also human and there have existent laws \& regulations to punish them after all.

Furthermore, it is must be notified that our Constitution, various Laws-Regulations and Treaty Conventions never support extra-judicial killings and there is no doubt about it. This is the impunity of our legal system that it is prohibited but can't stop for our lacking and weakness. So, it is clear that criminal and non-criminal both are human and they have right to enjoy their rights. If they have done any wrong or unlawful acts then there have rules-laws of justice of the government by which they will be justified first and then punished. Finally, to strengthen the relations as well as to reducing the existing role of the police regarding extra-judicial killings, distances between the law enforcement agency and the public, this agency should also be more dedicated to human rights. This is possible when they begin to think of themselves as people's servants, not thinking as the upwards of the people rather as a part of the people in a democratic UniversePG I www.universepg.com and developing country like Bangladesh (Dr. Mizanur Rahman, February 2018:67).

\section{CONCLUSION:}

After a critical analysis of the study, it has been noticed and observed by the researcher that lots of extreme violations have been committed by the law enforcement agencies i.e., by the police especially a section of corrupted officials in the department of police. In addition to this, it is pertinent to be mentioned that the police as well as mostly RAB is highly related to occur such violations. After analyzing the violation of human rights concerned with certain years' reports reported in different human rights organizations and mass media in a country like Bangladesh, it would not be out of place to mention that reported violations of human rights played and directed nothing expected positive role of this law enforcing agencies i.e., the police rather the precedent of extreme violations in respect of ExtraJudicial Killing has been alarmingly increasing day by day. In addition to this, it is observed that the activities of the law enforcers have been moderated through different methods of committing violations where the accountability have become covered by the illegal practice of law. Therefore, certain domestic laws and international instruments have been grossly violated in action of dramatic role of the law enforcers i.e., the police. Even more, the guidelines directed by the supreme institution i.e., have not been properly followed rather been violated rampantly. Most importantly, it is to be mentioned that political influences worked largely in every sphere of conducting services towards the citizens. Furthermore, countrywide violation of human rights loomed among the people become more ferocious to commit crimes again and again thinking that justice never be done by the law enforcers where this agencies have already become more corrupted. After critical analysis regarding the violation of human rights, it has been observed that recruitment of the law enforcement agencies i.e., the police,' should be strictly maintained to hold the fair appointment. Therefore, finally it can be said that the government should strictly maintain the quality police appointing in the law and order perspective where there would be absolute transparent of accountability to be ensured regarding the violation 
of human rights in a democratic and developing country like Bangladesh. Indeed, there should have the necessary action taken by the government in all circumstances for establishing rule of law. Because if the rule of law i.e., the proper implementation and application of law could be ensured in a democratic country like Bangladesh, then it would not be difficult to ensure human rights in a state like Bangladesh.

\section{ACKNOWLEDGEMENT:}

This study was supported with proper supervision and help of Professor Dr. M. Anisur Rahman, Department of Law, University of Rajshahi, Bangladesh.

\section{CONFLICTS OF INTEREST:}

The author declared no prospective conflicts of the interest with respect to the research work.

\section{REFERENCES:}

1. “Annual Human Rights Report." (2016). Odhikar, (2009): 20, quoted in Md. Kamruzzaman et al., "Extrajudicial Killings: The Violation of Human Rights in Bangladesh," International $J$. of Environmental Management, 2(4), 23.

2. “Annual Human Rights Report." (2016). Odhikar, (2010): 22, quoted in Md. Kamruzzaman et al., "Extrajudicial Killings: The Violation of Human Rights in Bangladesh," International J. of Environmental Management, 2(4), 23.

3. “Annual Human Rights Report." (2016). Odhikar, (2011), quoted in Md. Kamruzzaman et al., "Extrajudicial Killings: The Violation of Human Rights in Bangladesh," International J. of Environmental Management, 2(4), 24.

4. "Annual Human Rights Report." (2016). Odhikar, (2012):101, quoted in Md. Kamruzzaman et al., "Extrajudicial Killings: The Violation of Human Rights in Bangladesh," International Journal of Environmental Management, 2(4), 24.

5. "Bangladesh Annual Human Rights Report 2017." (January 12, 2018): 29-31, 2018.

6. "BANGLADESH: Rapid Action Battalion shot innocent college student into permanent disability and now threatening sympathizers to kill extra-judicially," Asian Human Rights Commission, Accessed May 22, 2018, http://www.humanrights.asia/news/urgent-appeals/AHRC-UAC-075-2011

7. "Death for 15, life term for 11," The Daily Star, last modified (August 23, 2017). Accessed May 23, 2018, https://www.thedailystar.net/frontpage/narayang anj-7-murder-verdict-high-court-bangladesh-death-reference-appeal-death-15-life-term-11-145$\underline{2607}$

8. "Ignoring Executions and Torture Impunity for Bangladesh's Security Forces." (2016). Human Rights Watch, (2009): 52, quoted in Md. Kamruzzaman et al., "Extrajudicial Killings: The Violation of Human Rights in Bangladesh," International J. of Environmental Management, 2(4), 23.

https://www.hrw.org/reports/2006/bangladesh12 $\underline{06 /}$

9. "Notable Arrests," Wikipedia, the free encyclopedia, accessed May 25, 2018,

https://en.wikipedia.org/wiki/Rapid_Action_Batt alion

10. "Rapid Action Battalion," Wikipedia, the free encyclopedia, accessed March 9, 2018,

https://en.wikipedia.org/wiki/Rapid_Action_Batt alion

11. "Timeline of N'ganj 7-murder," The Daily Prothom Alo, last modified (January 16, 2017). 2018.

http://en.prothomalo.com/bangladesh/news/1360 87/Timeline-of-N\%E2\%80\%99ganj-7-murder

12. Aziz, Moonmoon Binta. (December 2015). "Extra Judicial Killing: An Overview of Bangladesh," BEST: International J. of Humanities, Arts, Medicine and Sciences. 3(12), 131-132, 2018.

13. Bureau of Democracy. (2016): Human Rights, and Labor 2009 Country Reports on Human Rights Practices Report, quoted in Md. Kamruzzaman et al., "Extrajudicial Killings: The Violation of Human Rights in Bangladesh," International J. of Environmental Management, 2(4), 22.

https://www.state.gov/j/drl/rls/hrrpt/2009/sca/13 $\underline{6085 . h t m}$ 
14. Das, Shashi Kanto et al., (2016). "Preventive Detention and Section 54 of the Code of Criminal Procedure: The Violation of Human Rights in Bangladesh," American J. of Business and Society, 1(3), 60-67, 2018.

15. Huq, Zahirul. (2016). The Penal Code, 1860, $10^{\text {th }}$ ed., (Dhaka: Bangladesh Law Book Company, 2006), quoted in Md. Kamruzzaman et al., "Extrajudicial Killings: The Violation of Human Rights in Bangladesh," International $J$. of Environmental Management, 2(4), 22.

16. Islam MN. (2019). A Comparative Study Relating to Community Policing in the Context of Bangladesh, Br. J. Arts Humanit., 1(6), 56-72. https://doi.org/10.34104/bjah.019.56072

17. Islam, Md. Nahidul. "Human Rights Situation in Bangladesh: A Study with Special Reference to the Role of Police." $\mathrm{PhD}$ thesis. University of Rajshahi, 2018.

18. Kamruzzaman, M. and. Hakim, M. A. (2015). "Child Criminalization at Slum Areas in Dhaka City," American J. of Psychology and Cognitive Science, 1(4), 107-111.

19. Kamruzzaman, Md. et al., (2016). "Extrajudicial Killings: The Violation of Human Rights in Bangladesh," International J. of Environmental Management, 2(4), 24-25, 2018.

20. Manabadhikar Khabar, (August 2013): 13, quoted in Md. Kamruzzaman et al., "Extrajudicial Killings: The Violation of Human Rights in Bangladesh," International $J$. of Environmental Management, 2(4), (2016): 24.

https://www.researchgate.net/publication/31883 4940
21. Razia, Sultana. (2016). "Extrajudicial Killings in the Name of Crossfire," Human Rights Solidarity (2005), quoted in Md. Kamruzzaman et al., "Extrajudicial Killings: The Violation of Human Rights in Bangladesh," International $J$. of Environmental Management, 2(4), 22.

22. Riti, Tamanna Hoque. (December 2017). Human Rights Bangladesh 2016, [Dhaka: Ain O Salish Kendra (ASK)], 44.

23. The Constitution of the People's Republic of Bangladesh, Article 32.

24. The Constitution of the People's Republic of Bangladesh, Article 6: Every human being has the inherent right to life. This right shall be protected by law. No one shall be arbitrarily deprived of his life.

25. The Daily Star, "'Shootouts' not ending." (May 25, 2018). Accessed May 25, 2018.

http://epaper.thedailystar.net/index.php?op\%20t =view $\&$ page $=1 \&$ date $=2018-05-25$

26. The Daily Star, "Rough despite stern warning," accessed February 7, 2016.

http://epaper.thedailystar.net/index.php?opt=vie w\&page $=1 \&$ date $=2016-02-05$

27. Wehmeier, Sally. (2016). Oxford Advanced Learner's Dictionary, $6^{\text {th }}$ ed., Oxford University Press, quoted in Md. Kamruzzaman et al., "Extrajudicial Killings: The Violation of Human Rights in Bangladesh," International J. of Environmental Management, 2(4), 21-22.

28. Wikipedia, the free encyclopedia, "Death squad." Accessed May 25, 2018.

https://en.wikipedia.org/wiki/Death_squad

29. Wikipedia, the free encyclopedia, "Extrajudicial killing," accessed May 25, 2018. https://en.wikipedia.org/wiki/Rapid_Action_Batt alion

Citation: Islam MN. (2020). A critical analysis on violation of human rights caused by extra-judicial killings with special reference to the role of police: Bangladesh perspective, Asian J. Soc. Sci. Leg. Stud., 2(1), 11-32.

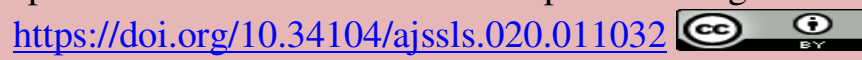

